\title{
Cancer stem cells - from initiation to elimination, how far have we reached? (Review)
}

\author{
KAMAL AKHTAR, WENDY BUSSEN and SHAUN P. SCOTT \\ Department of Radiation Oncology, Washington University School of Medicine, St. Louis, MO 63108, USA
}

Received January 12, 2009; Accepted February 23, 2009

DOI: $10.3892 /$ ijo_00000278

\begin{abstract}
Cancer stem cells (CSCs) are rare tumor cells that have the potential to proliferate, self-renew and induce tumorigenesis. Over the past few years, CSCs have been isolated from several different tumors and when implanted into immune-deficient mice, generate tumors that are identical to the parental tumors. In this review, we summarize the current literature on CSCs, which suggests that since these cells have the ability to drive tumor formation, specifically targeting them may lead to more effective therapies against tumors.
\end{abstract}

\section{Contents}

1. Introduction

2. Discovery of cancer stem cells in multiple cancers

3. Signaling pathways in cancer stem cells

4. Origin of cancer stem cells

5. Mechanism of cancer stem cells

6. On the way to eliminate cancer stem cells

7. Summary and future prospects

Correspondence to: Dr Shaun P. Scott, Department of Radiation Oncology, Washington University School of Medicine, St. Louis, MO 63108, USA

E-mail: sscott@radonc.wustl.edu

Abbreviations: CSCs, cancer stem cells; NOD-SCID, non-obese diabetic, severe combined immunodeficient; CC-ICs, colon cancer initiating cells; BTSCs, brain tumor stem cells; HSCs, haematopoitic stem cells; AML, acute myelogenous leukemia; SL-IC, SCID leukemia-initiating cells; SP, side population; BASCs, bronchioalveolar stem cells; MIS, Mullerian inhibiting substance; DBH, debromohymenialdisin; HNSCC, head and neck squamous cell carcinoma; BTICs, brain tumor initiating cells; NSP, non-side population; CML, chronic myelogenous leukemia; LSCs, leukemic stem cells; BCC, basal cell carcinoma; T-ALL, T-cell acute lymphoblastic leukemias

Key words: cancer stem cells, solid tumors, tumor initiation and progression, metastasis, cancer stem cell marker, tumor therapy, leukemia, self-renewal

\section{Introduction}

Despite many advances in the early detection and treatment of cancers, patient mortality rates remain high. This is due in part to the survival of chemo- and radio-resistant cancer stem cells following treatment. Cancer stem cells (CSCs) are defined as cells within a tumor that possess the capacity to self-renew and differentiate into the heterogeneous lineages of cancer cells that comprise the tumor. Like ordinary cells, CSCs appear to be quiescent for much of their life, dividing on occasion to give rise to two daughter cells, either two replicas of itself (stem cell) or one stem cell and the other a more differentiated progenitor cell capable of further differentiation when given the appropriate signals. CSCs drive tumorigenesis and give rise to a large population of differentiated progeny that make up the bulk of the tumor and lack tumorigenic potential. While isolation of CSCs has only recently occurred (see below), the concept of CSCs has been around for $>40$ years. Decades ago, cancer researchers noted that tumors are composed of multiple cell types that appear to have originated from a common ancestor cell and that while chemotherapy and radiation treatment may eradicate a tumor, the cancer can re-grow and metastasize (1). These observations lead to the conclusion that a small subset of cells in a tumor has the ability to sustain and re-create the tumor, although many uncertainties still remain. It is becoming evident that CSCs are the only cells in malignancy which have the ability to expand, promote tumor growth as well as metastasize. Despite several studies which question the existence of such cells $(2,3)$, two general assumptions in the field of CSC biology are that treatments which fail to eliminate CSCs may allow re-growth of the tumor and specifically targeting CSCs may cure cancers. Identification and characterization of CSCs may lead to important advances in our understanding of cancer biology and pave the way for the development of drugs that specifically target CSCs.

\section{Discovery of cancer stem cells in multiple cancers}

The first conclusive evidence for the existence of CSCs was published in 1997 by Bonnet and Dick who studied acute myelogenous leukemia (AML) (4). They isolated cells from a patient with AML and found that only a subset of the total cells, termed SCID leukemia-initiating cells (SL-ICs), were capable of initiating leukemia after transplantation into a non-obese diabetic, severe combined immunodeficient (NOD/SCID) mouse. SL-ICs carried the unique cell surface 
antigen CD34 but were negative for CD38 (CD34+CD38-) (Table I). When injected into a recipient mouse, CD34+CD38 cells initiated leukemia that expressed the same aberrant combination of surface antigens typical of the patient sample, whereas other leukemia cells could not. Bonnet and Dick also provided evidence that leukemia-initiating transformation and progression-associated genetic events occur in primitive cells and not in committed progenitors and the nature of the genetic defect itself determines the differentiation program of the leukemic clone. These results suggested that SL-ICs originated from normal stem cells rather than from progenitors and have the properties of self-renewal, proliferation and differentiation, characteristic features of stem cells (4). However, not all CSCs appear to arise from normal stem cells and this issue will be discussed.

The differentiation hierarchy of normal stem cells and the markers that identify them are not well characterized in most organs. However, significant similarities have been found between CSCs and normal stem/progenitor cells in solid tumors. Researchers have succeeded in isolating sub-populations of tumor cells with stem cell-like features and with tumorigenic capabilities from many solid tumors. Al-Hajj and colleagues (5) were the first to report the presence of CSCs in breast cancer. They isolated a distinct population of cells from a human breast cancer that have the ability to form tumors when engrafted into NOD/SCID mice and they termed these cells tumor initiating cells. These distinct cells expressed the cell surface marker $\mathrm{CD}_{44}{ }^{+} \mathrm{CD} 24^{- \text {llow }}$ lineage- ${ }^{-}$and as few as 1000 $\mathrm{CD} 44^{+} \mathrm{CD} 24^{-/ \text {low }}$ lineage ${ }^{-}$cells were able to generate tumors in NOD/SCID mice.

Breast cancer consist of a heterogeneous population of cells with very few $\mathrm{CD} 44^{+} \mathrm{CD} 24^{- \text {llow }}{ }^{\text {lineage }}$ CSCs and a much larger population of cells that lack tumorigenic potential. When engrafted into NOD/SCID mice, the tumorigenic cells gave rise to both $\mathrm{CD} 44^{+} \mathrm{CD} 24^{-/ \text {low }}$ lineage cells and to phenotypically diverse non-tumorigenic cells, thus simulating the complexity of the primary tumors from which the tumor initiating cells had been derived. The $\mathrm{CD} 44^{+} \mathrm{CD} 24^{-/ \text {low }}$ lineage cells were serially passaged through four rounds of tumor formation in mice, yielding similar results in each passage with no evidence of decreased tumorigenicity, suggesting that CD $44^{+} \mathrm{CD} 24^{-/ \text {low }}$ lineage ${ }^{-}$cells undergo a process analogous to the self-renewal and differentiation of normal stem cells. Thus, $\mathrm{CD} 44^{+} \mathrm{CD} 24^{- \text {-low }}$ lineage ${ }^{-}$cells exhibited the properties of cancer stem cells, that have the ability to proliferate extensively and give rise to diverse cell types with reduced development or proliferative potential. Together these results showed that while some breast cancer cells have the ability to proliferate extensively, the majority of cells derived from a tumor have only limited proliferative potential in vivo (5).

More recently, CSCs have been isolated from some, but not all, brain cancer (6), lung cancer (7), prostate cancer (8), melanoma (9), ovarian cancer (10), colon cancer (11), head and neck cancer (12), pancreatic cancer (13) hepatocellular cancer (14), bladder cancer (15) and skin cancer (16) (Table I). In all cases, xenotransplant assays have been employed to prove cancer stemness. However, there is still debate regarding how realistically xenograft models recapitulate human tumors. Studies have suggested that xenograft models might underestimate the number of tumor-initiating cells (17). In addition,
Table I. CSC markers in different cancers.

\begin{tabular}{|c|c|}
\hline Cancer type & Stem cell markers \\
\hline Leukemia & $\mathrm{CD} 8^{-\mathrm{CD}} 34^{+}(4)$ \\
\hline Breast & $\mathrm{CD}_{4}{ }^{+} \mathrm{CD} 24^{-/ \text {low }}$ lineage $^{-}(5)$ \\
\hline Brain & $\mathrm{CD}_{133}{ }^{+}(6)$ \\
\hline Lung & $\mathrm{Sca}^{+} \mathrm{CD} 34^{+}(7)$ \\
\hline Prostate & $\mathrm{CD}_{4} 4^{+} \alpha \beta^{\mathrm{hi}} \mathrm{CD} 133^{+}(8)$ \\
\hline Melanoma & $\mathrm{CD} 20^{+}(9)$ \\
\hline Ovarian & $\begin{array}{l}\text { Hoechst effluxing, verapamil sensitive and } \\
\mathrm{BRCP} 1^{+} \mathrm{SP} \text { (side population) cells (10) }\end{array}$ \\
\hline Colon & $\mathrm{CD}_{133}+(11)$ \\
\hline Head and neck & $\mathrm{CD} 44^{+}(12)$ \\
\hline Pancreatic & $\mathrm{CD}_{4} 4^{+} \mathrm{CD} 24^{+} \mathrm{ESA}^{+}(13)$ \\
\hline Hepatocellular & $\mathrm{CD} 90^{+} \mathrm{CD} 44^{+}(14)$ \\
\hline Bladder & $\mathrm{EMA}^{-C D} 44 \mathrm{v}^{+}(15)$ \\
\hline Skin & $\mathrm{CD}^{3} 4^{+}(16)$ \\
\hline
\end{tabular}

tumor cell fractions injected into different sites (eg, subcutaneous, renal capsule) of the same mouse can form a tumor at one site but not another (17). Another potential problem with the use of immunodeficient mice is that they lack lymphocytes and macrophages, both of which are known to play important roles in tumor growth, angiogenesis, and metastasis (18). Regardless of these limitations, it has been shown that CSCs i) represent a small fraction of the total cells comprising the tumor, ii) express specific cell surface markers and iii) have the potential to self-renew and differentiate. Injection of as low as $100 \mathrm{CSCs}$ into SCID/NOD mice produced a tumor that could be serially transmitted from mouse to mouse. In addition, the cellular heterogeneity and architecture of tumors originated from these mice closely resembled those of patient tumors from which the cells were originally taken.

However, it is still under debate as to whether the cells being sorted from tumors are truly CSCs as there are several controversial studies regarding the specificity of CSC markers (3). For example, CD133 is recognized as a stem cell marker for normal and cancerous tissues and CD133 alone or in combination with other markers is currently used for the isolation of CSCs from a variety of tumors such as brain, colon and prostate cancers. Recently, Shmelkov et al used a knock-in LacZ transgenic approach that showed that CD133 is not expressed exclusively in CSCs, but rather is widely expressed in normal adult tissues (19). Furthermore, they found that both $\mathrm{CD}_{133^{+}}$and $\mathrm{CD} 133^{-}$cells formed colonospheres in in vitro cultures and were capable of initiating tumorigenesis in NOD/SCID mice (19). Thus, these results suggest that no single marker is likely to be absolutely informative, and better techniques and assays will be required for the validation of CSC markers. 


\section{Signaling pathways in cancer stem cells}

The most important property of any stem cell is the ability to self-renew via a unique cell division in which the capacity of one or both progeny to proliferate and differentiate is similar to those of the parental cell. It is thought that most tumors develop through a series of mutations that occur over a period of months to years. Adult stem cells are slowly dividing long-lived cells, which are exposed to a range of damaging agents over long periods of time. Therefore, they may accumulate mutations that i) turn on genes that promote proliferation, ii) silence genes involved in the inhibition of proliferation, iii) circumvent genes involved in apoptosis and/or iv) disrupt genes involved in the regulation of stem cell self-renewal.

CSCs retain both the features of self-renewal and differentiation but have lost the homeostatic mechanism which maintains normal cell number. There are striking parallels between normal stem cells and CSCs. Both cell types share various markers of 'stemness'. In particular, normal stem cells and CSCs utilize similar molecular mechanisms and signaling pathways to drive self-renewal and differentiation. Still, it is unclear as to whether CSCs are heterogenous in nature with cells having varying self-renewal capacity or homogenous with all cells have equal self-renewal capacity. Many pathways that are classically associated with normal stem cell selfrenewal and differentiation can also regulate cancer. Recent advances in the understanding of the roles of the Notch, Wnt and Sonic hedgehog (Shh) signaling pathways in regulating stem cell self-renewal begin to shed new light on carcinogenesis. These signaling pathways are well conserved during evolution. In organisms such as $D$. melanogaster and C. elegans, they regulate morphogenesis, while in mammals they regulate proliferation and differentiation of various cell types at different stages of phylogenesis. These pathways help to maintain the proper balance between stem cells, progenitor cells and the differentiated compartment.

Notch signaling pathway. The Notch signaling pathway is well-conserved from nematodes to humans $(20,21)$. In mammals, four Notch receptors (Notch1-Notch4) are present, and each receptor has a unique ligand (22). A number of in vivo and in vitro studies have demonstrated the roles of the Notch signaling pathway in stem cells, early progenitor cells and in the development of cancers. The involvement of Notch signaling in cancer was first identified in T-cell acute lymphoblastic leukemia (T-ALL) where chromosomal translocation $(7 ; 9)$ leads to the constitutive activation of Notch signaling (23-26) that was further demonstrated in a mouse model where expression of a constitutively active Notch1 protein led to the development of T-cell lymphoma $(27,28)$.

In addition, the vertebrate Notch4 gene has been shown to be involved in normal mammary development $(29,30)$ where it promotes self-renewal in stem cells and in the later stages of development it promotes mammary progenitor cell differentiation into myoepithelial cells $(29,30)$. In transgenic mice, expression of a constitutively active form of Notch4 inhibits differentiation of normal breast epithelial cells and leads to the development of mammary tumors in a dominant- negative manner (29,31-34). Taken together, these studies suggest that unregulated Notch signaling contributes to tumor development.

Notch signaling also plays a role in the renewal of existing cell populations through the proliferation of progenitor cells, particularly during epidermal wound repair or in neural cell replacement (35-37). Increasing evidence suggests that upregulation of Notch signaling leads to brain tumor development driven by brain tumor stem cells (BTSCs). Shih and Holland (38) found that in glioblastoma tissue samples, high levels of the neural stem cell marker nestin have been associated with high levels of Notch expression, suggesting that Notch signaling can play important roles in glial tumor development, particularly in promoting nestin expression that may contribute to stem cell potential. Altogether, these findings suggest that the constitutive activation of Notch signaling could be responsible for preventing differentiation and dysregulating cell proliferation, the consequences of which lead to neoplastic transformations.

Wnt signaling pathway. The Wnt signaling pathway plays an important role in embryogenesis, and abnormal Wnt signaling has been shown to lead to oncogenesis. Activating mutations of $\beta$-catenin or inactivating mutations of the adenomatosis polyposis coli (APC) gene, both components of the Wnt signaling pathway, occur in a large percentage of colon, endometrial, prostate and hepatocellular carcinomas $(39,40)$. In addition, constitutive activation of Wnt signaling triggers tumorigenesis in the skin (41), breast (42), bone marrow (43), chronic myelogenous leukemia (CML), sarcoma, multiple myeloma and brain tumors (39).

In addition to its crucial role in carcinogenesis, Wnt signaling also regulates stemness, proliferation, differentiation and self-renewal of stem cells and progenitor cells (44-46). It is assumed that the Wnt protein acts as a stem cell growth factor that promotes the maintenance and proliferation of stem cells $(39,47,48)$.

The longevity of stem cells makes them good candidates for tumor precursors (see discussion below) and a growing amount of literature suggest that Wnt-induced stem and/or progenitor cell amplification is likely to be a key step in tumor initiation. Since it has been shown that normal activation of Wnt signaling may promote self-renewal of neuronal stem cells, it is reasonable to hypothesize that aberrant Wnt pathway activation may be tumorigenic in the nervous system $(49,50)$. This idea is supported by the fact that medulloblastomas, a pediatric brain tumor of the cerebellum, harbor activating mutations in $\beta$-catenin (51) and axin (a negative regulator of the Wnt pathway) $(52,53)$ suggesting that some medulloblastomas may arise from uncontrolled Wnt signaling in primitive stem/progenitor cells. Furthermore, dysregulated Wnt signaling causes an excess proliferation of mammary progenitor cells and predisposes them to cancer. Expression of Wnt1 in the mammary glands of transgenic mice resulted in the expansion of population of epithelial cells expressing the progenitor cell markers keratin-6 and Sca-1, suggesting that progenitor cells are the precursor to the mammary tumor. Furthermore, subsequent tumors (from its progeny) express these markers, implying that they arose from a common progenitor. These tumors have an increased frequency of cells 
with stem and progenitor properties, in contrast to tumors from mice overexpressing other oncogenes, such as Neu or H-Ras $(42,54)$. This suggests that the Wnt pathway may be unique in its ability to target stem and progenitor cells for transformation and perhaps reflects a role of the Wnt pathway in self-renewal of normal breast epithelium (42).

It has been reported in HSCs that, activating Wnt signaling through $B$-catenin results in stem cell expansion, whereas ectopic expression of inhibitors of Wnt signaling reduces in vitro hematopoitic stem cell growth and in vivo reconstitution of HSCs (46). In contrast to this, Fleming et al recently demonstrated that Wnt signaling is required for the maintenance of the HSCs in a quiescent stage in bone marrow to preserve the reconstituting function (55).

Taken together, these studies support the notions that the Wnt pathway plays a crucial role in the maintenance of stem/ progenitor cells and dysregulation of Wnt pathway may lead to tumor development. Significantly, this pathway could potentially be an important therapeutic target in that blocking upstream or downstream components of the Wnt pathway may decrease or inhibit the signaling pathways required for CSC survival and self-renewal.

Sonic hedgehog (Shh) signaling pathway and Bmi-1. The Sonic hedgehog (Shh) pathway is important in growth and differentiation during embryogenesis and for proper functioning in many adult tissues. The first link between Shh signaling and cancer was shown in the hereditary disease Gorlin's syndrome, which predisposes individuals to multiple basal cell carcinomas (BCCs) in the skin, medulloblastomas, and rhabdomyosarcomas $(56,57)$. Gorlin's syndrome is caused by a germline mutation in the Shh receptor PATCHED1 $(\mathrm{PTCH})$ gene. It has been reported that overexpression of the downstream signaling targets of the Shh pathway, either Gli-1 or Gli-2, was sufficient for the formation of BCCs in murine models (58-61). Analysis of human sporadic medulloblastomas revealed PTCH inactivation in $20 \%$ of tumors and mice engineered to harbor a germline PTCH inactivating mutation developed medulloblastomas $(62,63)$. Other proteins involved in Shh signaling have also been found to be mutated or deregulated in brain tumors, including the transmembrane receptor smoothened $(\mathrm{SMOH})$, the gliomaassociated oncogene homologue transcription factors (Gli-1, Gli-2, Gli-3) and the suppressor of fused protein (SUFU) (64-67).

Liu et al (68) first elucidated the role of Shh signaling in the regulation of stem cell self-renewal by demonstrating that several components of the Shh signaling pathway, namely PTCH1, Gli-1, and Gli-2, were highly expressed in normal mammary stem/progenitor cells compared to differentiated cells on a collagen substratum (68). Activation of this pathway with Shh ligands promoted the self-renewal of mammary stem cells and the effect was blocked by cyclopamine, a specific inhibitor of this pathway (68). The Shh pathway also plays crucial roles in the expansion of human blood progenitors in immunocompromised mice (69). Furthermore, Clement et al (70) demonstrated that Shh signaling regulates expression of the stemness gene and functions in the self-renewal of CD133+ glioma CSCs, suggesting that the Shh pathway is important for proliferation, survival, self-renewal and tumorigenicity.
Liu et al (68) also showed that Shh signaling coordinates with the protein Bmi-1, a member of the polycomb group of genes, to regulate the self-renewal of stem cells. Bmi-1 (B lymphoma Mo-MLV insertion region) is a transcriptional repressor that controls target gene expression through chromatin modification (71). It is involved in the regulation of genes controlling cell proliferation, cell survival, differentiation as well as stem-cell-maintenance (72). Liu et al found that activation of Shh signaling increases Bmi-1 expression, which in turn promotes mammary stem cell self-renewal and proliferation both in vivo and in vitro. Specifically, it was demonstrated that overexpression of Gli-1 and Gli-2 in mammosphere-initiating cells resulted in increased Bmi-1 expression which increase the size and number of mammosphere. This effect was specifically blocked by the Shh pathway-specific inhibitor cyclopamine. Furthermore, NOD-SCID mice overexpressing Bmi-1 displayed increased ductal/alveolar hyperplasias (68).

Several studies of the Bmi-1 protein in normal stem cells support the idea that Bmi-1 promotes stem cell self-renewal. Bmi-1 has also been shown to play important roles in the self-renewal of hematopoietic and neuronal stem cells (72,73). Molofsky et al (73) examined the effect of Bmi-1 deficiency on the self-renewal of stem cells in the central nervous system (CNS) and neural crest and found that lack of Bmi-1 reduced the self-renewal of both CNS and neural crest stem cells (73). Furthermore, multiple laboratories have generated $\mathrm{Bmi}-1^{-/}$mice to investigate its role in stem cell self-renewal and found that Bmi-1-deficient HSCs were unable to self-renew (72-74). These results, together with the fact that Bmi-1 deficient mice die of bone marrow failure (75), indicate that Bmi-1 is essential for self-renewal of HSCs. The mechanism by which Bmi-1 modulates HSC self-renewal seems to be through repression of the genes encoding the p16 ${ }^{\text {Ink4a }}$ and $\mathrm{p} 19^{\text {Arf }}$ proteins that inhibit cell proliferation and enhance cell death, respectively $(72,73)$.

Lessard and Sauvageau (74) also linked Bmi-1 to the self-renewal of leukemic stem cells (LSCs). LSCs from Bmi-1deficient mice could not self-renew, resulting in far fewer leukemic cells in the blood of primary mouse recipients and an inability to produce leukemic cells in secondary recipients, suggesting that the self-renewal is an essential component of the development of leukemia (74). Altogether these data suggest that Bmi-1 is required for the self-renewal of stem cells and deregulation of this pathway leads to cancer.

Overall, it appears that deregulation of the self-renewal, proliferation and differentiation pathways in normal stem cells may play a role in the generation of CSCs that drives tumorigenesis. These pathways may act independently or may coordinate with each other to control different aspects of self-renewal pathway. Further studies will be needed to decipher these complex relationships.

\section{Origin of cancer stem cells}

The origin of CSCs is unclear. There is debate as to whether CSCs originate from i) normal stem cells that have lost the ability to regulate proliferation, ii) a more differentiated progenitor cells that have acquired the ability to self-renew, or iii) mature cells and cancer cells that have been 
reprogrammed by genetic and/or epigenetic events to gain self-renewal capacity and lose some features of differentiation. While mutations in normal stem cells could lead to the formation of CSCs in tissues with high rates of cellular turnover, such as skin or GI epithelium where stem cells are the only cells that live long enough to acquire enough genetic abnormalities to become cancerous, it is also possible that differentiated cells in which the genome is unstable could acquire the properties of stemness because of accumulation of mutations. For example, in chronic myelogenous leukemia (CML) committed granulocyte macrophage progenitors acquire the self-renewal capacity due to accumulated mutations, thus rendering them stem cell-like (4). Thus, it is possible that differentiated cells can, through multiple mutagenic events, acquire the self-renewal capacity and immortality that defines CSCs.

Acute lymphoblastic leukemia (ALL) is the most common cancer in pediatric patients. A majority of ALL cases involve the expansion of B-cell lymphoid progenitor cells (76). However, it has also been suggested that the expansion of T-cells as the origin of leukemia initiating cells in ALL (77). Taken together these data suggest that leukemia initiating cells share phenotypes with normal HSCs and ALL originates from the HSC compartment. Another study that analyzed the leukemia initiating cells in CML found that the LSC compartment may be dynamic: HSCs drive the initial phase of the disease and other committed compartments are responsible for the disease's progression via acquired mutations (78). New evidence indicates that LSCs can originate from normal blood stem cells or progenitor cells. In the case of chronic phase CML, LSCs arise from normal blood stem cells while in the case of blast crisis CML, they arise from more differentiated progenitor cells, thus the source of origin may change during disease progression (78).

Progenitor cells which lose the activity of self-renewal may lead to the generation of CSCs. In the case of CML, activation of B-catenin simply enhance the self-renewal activity of leukemic progenitor cells while keeping the overall gene expression profile of progenitor cells suggesting that LSCs can thus be generated from committed progenitors without widespread reprogramming of gene expression (78-80). Thus some CSCs may originate from normal progenitors by reactivating the self-renewal program while retaining the identity of committed progenitor cells.

Similar to normal stem cells, cancer cells also depend on dynamic interaction with adjacent stromal cells that comprise the tumor niche. As a tumor grows, the niche may change due to for example infiltration of immune cells and activation of the inflammatory response (81). This change in environment may lead to the generation of CSCs. Whether there is an environment in solid tumors that could be described as a 'cancer stem cell niche' remains to be established.

Thus, not all CSCs appear to arise via the same mechanism. Blood malignancies and solid tumors consist of a population of biologically distinct cancer cells. These cells are either stem cells that have mutated to undergo uncontrolled cell division and differentiation, progenitor cells that through mutations have regained the ability to self-renew, or CSCs that have arisen by the alteration of their niche (Fig. 1).

\section{Mechanism of cancer stem cell resistance}

Many of the mechanisms underlying tumor resistance remain elusive. Stem cells possess inherent mechanisms of protection that their differentiated progeny lack. Various types of membrane-spanning ATP binding cassette transporters, such as the multidrug-resistant gene1 (MDR1) and the breast cancer-resistant protein1 (BRCP1), contribute to the drug resistance of many cancers by pumping lipophilic drugs out of the cells. Activation of intracellular detoxifying systems and blockage of apoptosis also make CSCs more resistant to chemotherapeutic drugs (82), but how the small population of CSCs escapes various kinds of therapy and re-initiate tumor formation is largely unknown.

Stem cell subpopulations in many mammals, including humans, have been identified by the rapid efflux of Hoechst 33342 dye in flow cytometry and termed the side population (SP) (83-86). SP cells have been detected in several tumors, including breast cancer, lung cancer, ovarian cancer, glioblastoma, neuroblastoma and leukemia (10,87-90). These cells express high levels of the ABC transporter transmembrane proteins MDR1 and $\operatorname{BRCP1}(91,92)$, in addition to other transporter proteins, including ABCA3 and ABCG2 (88) and have a greater capacity to expel cytotoxic drugs such as mitoxantrone $(88,91,92)$, thus contributing to their high resistance to chemotherapeutic agents.

Liu et al (93) studied chemoresistance in glioblastoma and found that $\mathrm{CD} 133^{+}$brain tumor stem cells showed increased resistance to chemotherapeutic agents such as carboplatin, paclitaxel (Taxol), and etoposide as compared to CD133- cells. They (93) found that CD133+ cells express O6-methylguanineDNA methyltransferase (MGMT) at a higher level than CD133 cells, suggesting that chemoresistance may be substantially linked to MGMT-mediated DNA repair. In addition to the multidrug resistance gene BRCP1, anti-apoptotic genes, such as FLIP, BCL-2 and BCL-XL, and inhibitors of the apoptosis protein family (IAP) genes, such as cIAP2, cIAP2, NAIP and survivin were also found at higher expression levels in CD133+ CSCs (93). This study suggests that anti-apoptotic factors may also contribute to the drug resistance properties of CSCs as compared to normal stem cells.

Radiotherapy has been the most effective non-surgical treatment for cancer, yet recurrence is almost universal. Bao and colleagues (94) attempted to investigate the mechanism of radioresistance in glioblastomas. First, they showed that there is a small population of $\mathrm{CD} 133^{+}$cells which are highly resistant to radiation therapy and are responsible for the re-growth of the tumor after radiation treatment. In both cell culture and the brains of NOD/SCID mice, CD $133^{+}$glioma cells survived IR in increased proportions relative to CD133- cells (94). The $\mathrm{CD}_{133^{+}}$cells retained the ability to reinitiate heterogeneous tumors when transplanted into other mice, demonstrating the retention of stem cell ability. They further noted that while radiation treatment induced DNA damage to similar degrees in both $\mathrm{CD}_{133^{+}}$and CD133- cells from a glioma xenograft or human patient biopsy specimen, $\mathrm{CD} 133^{+}$cells were more resistant than their CD133- counterparts. The preferential survival of $\mathrm{CD}_{133^{+}}$cells after irradiation was due to lower rates of apoptosis, as evidenced by decreased activation of caspase- 3 and to efficient activation of DNA repair responses 

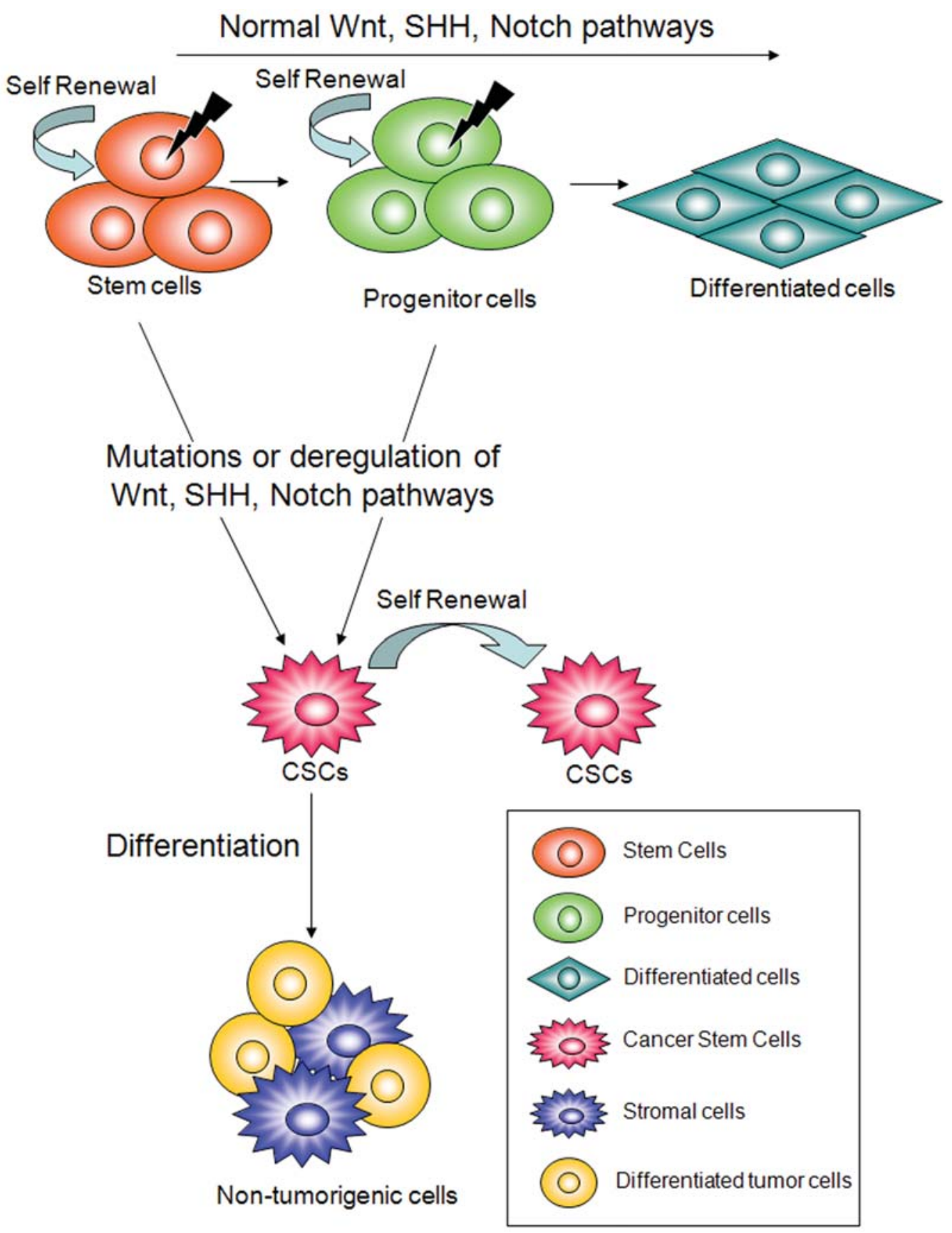

Figure 1. CSCs origin and their ability to self-renew. Self-renewal and differentiation are the hallmarks of stem cells. Normal Wnt, SHH, Notch signaling influences the self-renewal, proliferation and differentiation of stem cells or progenitor cells. Deregulation of these pathways can lead to constitutive or aberrant self-renewal pathways that in turn lead to cancer.

as indicated by phosphorylation of the ATM, Rad17, Chk1 and Chk2 proteins (94). The ability to repair DNA damage is essential to cellular survival as unrepaired DNA breaks induce apoptosis or senescence. Altogether, the study suggested that CD133+ CSCs contribute to glioma radioresistance through preferential activation of the DNA damage checkpoint response and an increase in DNA repair capacity.

When investigating radioresistance in breast cancer, it was found that breast cancer initiating cells were more radioresistant than non-breast cancer initiating cells. IR treatment in breast cancer initiating cells lowered the level of reactive oxygen species (ROS) followed by decreased double-strand break formation, thus resulting in increased radiation resistance $(95,96)$. Furthermore, progenitor cells in the mammary gland were more resistant to clinically relevant doses ( $2 \mathrm{~Gy})$ of radiation than non-progenitors which constitute the bulk of mammary gland $(95,96)$. Thus, the study of CSCs may provide insight into the underlying mechanisms of treatment failure, and as new studies emerge, it will be interesting to discover whether the mechanism of CSC resistance in other tumors is similar.

\section{On the way to eliminate cancer stem cells}

There is speculation that current cancer therapies, including radiation, chemotherapy and surgery often leave behind CSCs. The residual CSCs have the capability to give rise to a new tumor from a single cell missed by these therapies and 


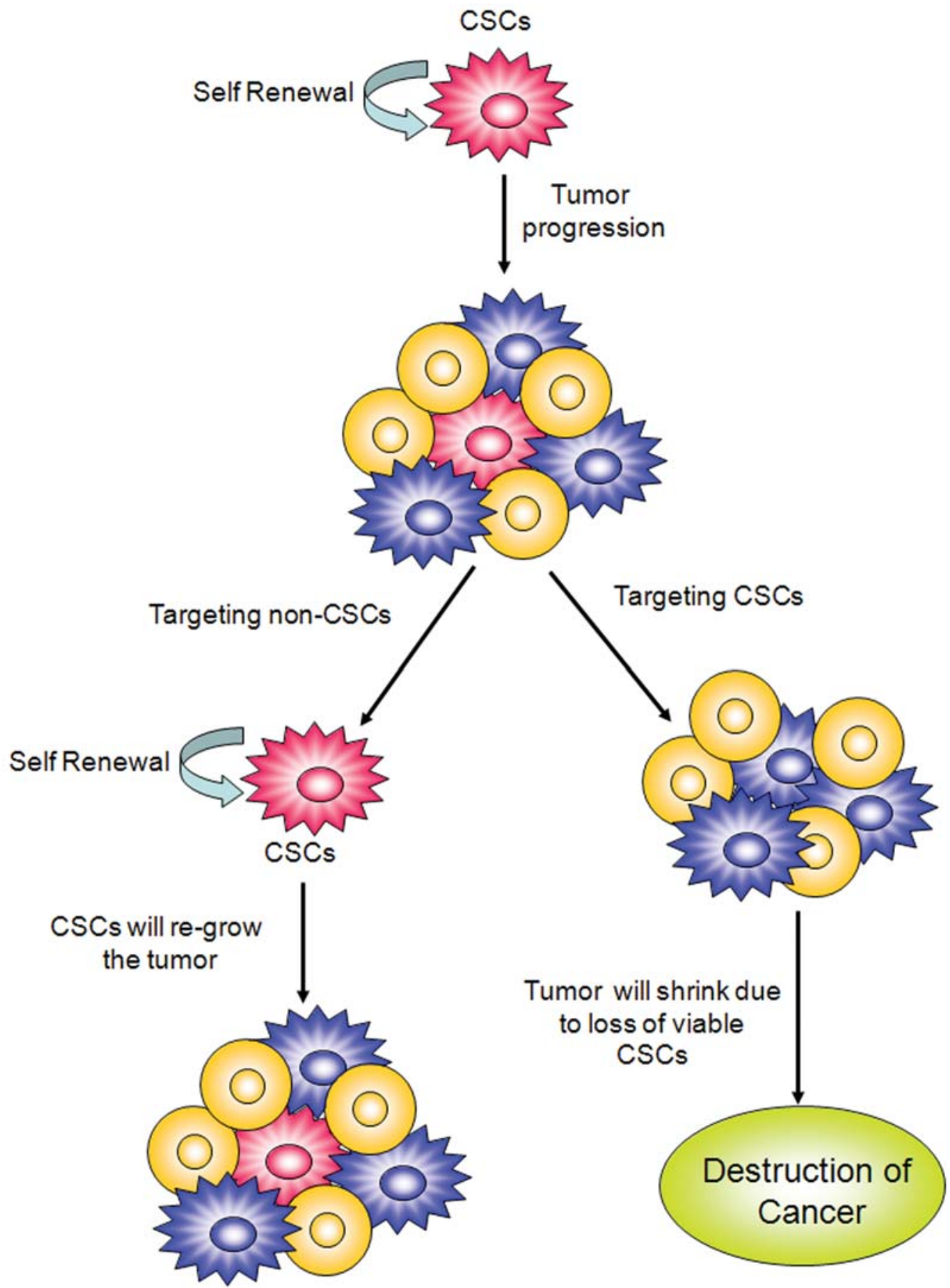

Figure 2. Proposed model for the treatment of cancer by targeting CSCs. Effective cancer treatments are only possible by targeting CSCs. Standard therapies may reduce the size of tumor by killing non-cancer stem cells, however targeting CSCs may lead to complete eradication of the cancer.

promote the metastasis of cancers to new sites around the body. These cells are capable of quietly living within the body for years and are able to restart tumor growth and metastasis even after a patient has been successfully treated with chemotherapeutics. Recurrence can take place in the first few years or as late as 20 years after the initial diagnosis. Isolating and characterizing CSCs paves the way for the creation of drugs to target them. Specifically destroying CSCs, the source of the cancer, could eliminate the disease more efficiently than treatments that randomly kill cancer cells. Traditional drug therapies have been developed based on the ability of the reagent to cause tumor regression in animal models. Because the majority of cancer cells within a tumor are non-tumorigenic, therapies directed at these cells cause tumor regression, but fail to target the tumorigenic CSCs. These cells then persist after therapy and are able to regenerate the tumor, resulting in tumor relapse. Effective tumor eradication will require agents that specifically target CSCs while sparing normal stem cells (Fig. 2). Thus, it is important that agents directed against CSCs discriminate between CSCs and normal stem cells. This will require identification of realistic drug targets unique to CSCs. Several approaches to this problem are discussed below.

It is becoming clear that HSCs reside in physiologically limited and specialized microenvironments termed 'niches' 
which maintain the balance between self-renewal and differentiation (97). Deregulation of factors provided by the niche that maintains this balance, leads to uncontrolled proliferation of stem cells and tumorigenesis (98). Targeting the interplay between stem cells and their niche pharmacologically may lead to better treatments of cancer. Promising studies show that stem cells isolated from AML patients display differences from normal HSCs (99). Although little is known of the molecular basis of self-renewal, it is becoming clear that survival and self-renewal of normal HSCs have an extrinsic component provided by the niche. If AML LSCs possess unique requirements for interaction with a niche, targeting this association might be an effective therapeutic approach to potentially inhibit their proliferation, induce differentiation, or stimulate apoptosis. Jin and colleagues (99) pursued this idea and reported a therapeutic approach using an activating monoclonal antibody (mAb H90) directed to the adhesion molecule CD44. CD44 is a ubiquitously expressed transmembrane glycoprotein that mediates cell-cell and cell-extracellular matrix interaction. CD44 is a key regulator of AML LSC function and is essential for proper homing of AML-LSCs to microenvironment niches and for maintaining AML-LSCs in their primitive state (100). Ligation of CD44 by activating mAb (H90) efficiently and selectively eradicated AML LSCs in vivo by blocking LSC trafficking to a supportive microenvironment and by altering their stem cell fate. H90 treatment, either in vivo or in vitro, effectively blocked the homing of leukemic cells, including primitive CD34 ${ }^{+}$CD38- SL-ICs to both the bone marrow and spleen (99). In vivo, disruption of CD44-mediated LSC-niche interaction may induce cell commitment at the expense of self-renewal and promote some level of differentiation. Differing effects of H90 on normal HSCs versus AML-LSCs are due to cell autonomous differences in CD44 structure and signaling. AML LSCs are probably more sensitive to $\mathrm{H} 90$ induced eradication as a result of the greater abundance of CD44 on their surface as compared with normal $\mathrm{CD} 34{ }^{+} \mathrm{CD} 38$ - cells (99). In vivo administration of this $\mathrm{mAb}$ to NOD/SCID mice transplanted with human AML markedly reduced leukemic repopulation. Furthermore, the absence of leukemia in serially transplanted mice demonstrated that AML LSCs were directly targeted (99).

Preliminary studies in solid tumors also suggested that CSCs require a niche. Calabrese et al (101) demonstrated that CSCs in brain tumors, similar to normal neural stem cells (NSCs), reside in vascular niches where vascular endothelial cells (ECs) secrete factors that promote stem cell survival and self-renewal. Co-transplantation of tumor cells with ECs in immunocompromised mice lead to more rapid tumor formation. Furthermore, these tumors contained more CSCs suggesting that ECs enhanced the self-renewal of CSCs in vitro and promoted the growth of brain tumors in vivo. Thus, tumor microvasculature generates specific microenvironments that promote the formation and/or maintenance of CSCs. The recruitment of an aberrant vascular niche is an important component in the progression and invasion of tumors. Furthermore, glioblastoma CSCs promote tumor angiogenesis through elevated expression of vascular endothelial growth factor (VEGF) (94). Thus disruption of this niche could prove a highly effective treatment of cancer. Anti-VEGF treatment by the Bevacizumab antibody specifically depletes tumor blood vessels and self-renewing CSCs from both medulloblastomas and glioblastomas, resulting in tumor growth arrest but have little effects on non-CSCs $(94,101)$.

CSCs can also be targeted by differentiating agents that induce stem cells to divide into two progenitor cells rather than dividing into two identical daughter cells with stem cell properties. Promoting this form of division would be a way to deplete cancer stem cell populations and may constitute an alternative strategy to inducing cell death to treat cancer. Piccirillo and colleagues (102) reported a role for the bone morphogenetic protein BMP4 in the differentiation of brain tumor stem cells (BTSCs) in glioblastomas (GBM). BMPs are soluble factors that normally induce neural precursor cells to differentiate into mature astrocytes, a subtype of brain cells. BMP4 treatment of cultured glioblastoma progenitor cells or $\mathrm{CD}_{133^{+}}$glioblastoma cells reduced cell proliferation and induced cell differentiation predominantly into cells resembling mature astrocytes. Thus, BMP4 produces a pro-differentiation action in GBM cells that leads to depletion of the pool of BTSCs (102). When NOD/SCID mice were transplanted with BMP4-treated glioblastoma progenitor cells or $\mathrm{CD}_{133^{+}}$cells, there was a significant decrease in the size of tumors in recipient mice and $\mathrm{CD} 133^{+}$cells could not be recovered from these tumors. Furthermore, three to four months post-injection, all control mice (mice receiving BMP4 un-treated cells) died, whereas nearly all mice receiving BMP4 pre-treated cells survived (102). Thus, transient exposure to BMP4 depleted the BTSC population and produced a significant decrease in the in vivo tumor initiating ability of GBM cells (102). Although these results were remarkable in showing the effectiveness of a differentiation promoting agent as a potential treatment for brain tumors, it will be interesting to explore the effects of differentiating promoting agents in other tumors as well.

Growing literature suggests that CSCs often have deactivated checkpoint responses as compared to that of normal stem cells. While the cell cycle of normal stem cells is tightly controlled by checkpoints to maintain genomic stability and integrity, the defective checkpoint responses associated with early cancer development implicate abnormal checkpoint control as a potential contributor to the transformation of normal stem cells into CSCs. This was demonstrated by Bao and colleagues (94), who suggested that CD133+ cancer cells contribute to glioma radioresistance and tumor repopulation through a preferential checkpoint response and DNA repair. They showed that targeting the checkpoint response in $\mathrm{CD}_{133^{+}}$cancer cells can overcome glioma radioresistance both in vivo and in vitro and provided a therapeutic model for malignant brain cancers. Pretreatment of CD133+ and CD133glioblastoma cells with debromohymenialdisine (DBH), a Chk1 and Chk2 inhibitor, minimally impacted the proliferation of both $\mathrm{CD}_{133^{+}}$and CD133- cells, but showed synergy with ionizing radiation (IR) to disrupt the radioresistance of $\mathrm{CD}_{133^{+}}$cells in vitro as well as in vivo, suggesting that a preferential checkpoint response in $\mathrm{CD}_{133^{+}}$cancer cells is closely associated with cellular resistance to radiation (94). Multiple therapies targeted to checkpoint kinases are in preclinical and clinical development and may provide a specific method to disrupt this resistance mechanism and improve overall tumor control in conjunction with radiation treatment. 


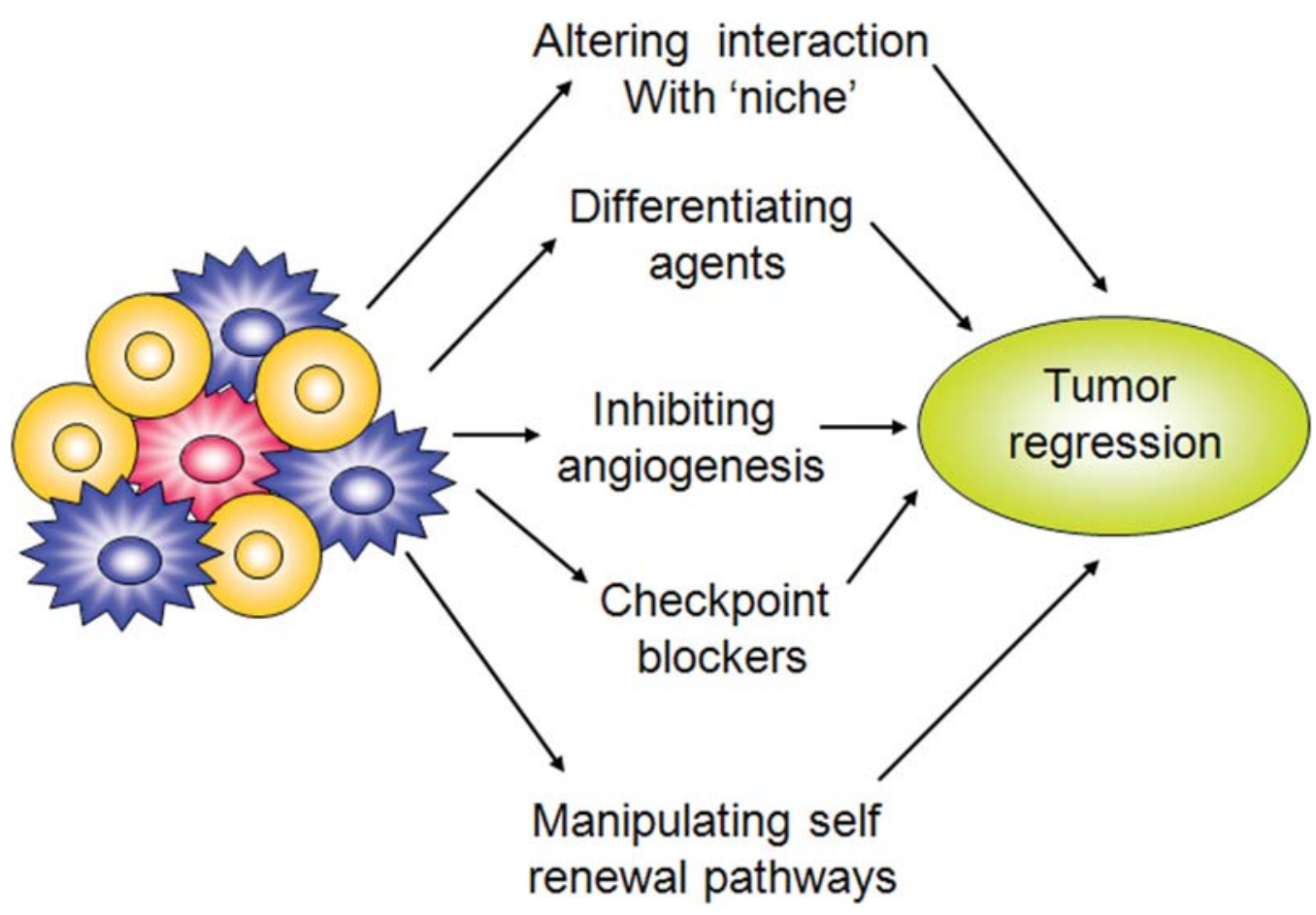

Figure 3. Potential cancer therapies. Future therapies for cancer might target CSCs by altering signaling pathways, inducing differentiation, altering the cell cycle, inhibiting angiogenesis, altering the interaction with the niche or by a different combination.

Several signaling pathways, such as Notch, Wnt and Sonic hedgehog $(\mathrm{SHH})$, play a central role in modulating the delicate balance between stemness and differentiation (discussed above). Blocking downstream or upstream components of these signaling pathways could potentially decrease or inhibit the signaling required for CSCs to survive and self-renew. For example, Fan et al (103) showed that blocking the Notch pathway in medulloblastomas depleted a population of cells required for in vivo tumor formation. Pharmacologically blocking the $\gamma$-secretase complex (a component of Notch pathway) decreased the quantity of CD133+ BTSCs in culture by inhibiting cell proliferation and inducing apoptosis or differentiation (103). When implanted into nude mice, cells treated with a $\gamma$-secretase inhibitor demonstrated a reduced ability to form tumors. Notch blockade depletes stem-like cells but leaves many better differentiated cells that are capable of limited growth intact, suggesting that Notch pathway blockers may be the first of a new class of chemotherapeutic agents for specifically targeting CSCs (103). Since aberrantly activated Notch signaling has been documented in lung, breast, salivary gland and pancreatic carcinomas (104-107), disrupting Notch pathway components may be useful in targeting stemlike cancer cells in a wide range of neoplasms. Furthermore, inhibition of Wnt signaling components by small molecule inhibitors, siRNA, anti-Wnt antibodies, or by reversal of epigenetic silencing induced apoptosis and suppressed cell growth both in vivo and in vitro in a variety of cancers and cancer cell lines (108-113). In addition, small molecule inhibition of the SHH pathway has successfully suppressed proliferation and induced apoptosis in murine tumor models (114). Of all the components of the SHH pathway, SMOH appears to be the most suitable drug target, being especially susceptible to the effects of small molecules in manipulating normal regulation of the pathway (115). Cyclopamine (an antagonist of SHH pathway that binds to $\mathrm{SMOH}$ ) has been successfully used to inhibit medulloblastoma cell growth both in cell culture and in mouse models (116). However, in vitro models of these antagonists did not provide convincing evidence of specificity to the SHH pathway $(117,118)$, suggesting that more specific pathway inhibitors need to be developed before this approach may be of therapeutic value.

Together, these studies suggest that utilizing what is known about the biological mechanisms of CSCs and how they differ from normal stem cells could provide clues to specific therapeutic targets that can more effectively eliminate CSCs while sparing normal stem cells. Furthermore, identifying regulators of CSCs that are less critical in normal stem cell biology and exploring the origin of this cellular niche and the underlying molecular mechanisms will be important in achieving greater success in control of CSC growth.

\section{Summary and future prospects}

In recent years, there has been a surge of interest in CSC biology, owing to landmark discoveries and emerging concepts which have provided a better understanding of the events leading to the development of CSCs. Thus far, studies have revealed that only a small subset of cells $(<10 \%)$ in tumors is capable of tumor re-initiation, which is consistent with the cancer stem cell hypothesis. As of today, CSCs have been identified and characterized from leukemia, breast, brain, lung, prostate, melanomas, ovarian, colon, head and neck, pancreatic, liver, bladder and skin cancers. These cells express distinct cell surface markers (Table I) which have the potential to be used for further purifying and functionally characterizing 
the biological properties of the CSCs. It will be important to develop cell surface marker and activity profiles in other tumors as well so that they can be used to reliably identify CSCs. Furthermore, markers that are not expressed by normal stem cells or non-tumorigenic cancer cells are of particular importance as they will aid in developing new therapeutic strategies directed specifically against CSCs. A number of studies have shown that CSCs have the capacity to self-renew and differentiate, however, it is still unclear that for how long CSCs have the capacity to self-renew. It will also be interesting to determine whether all cells of CSCs have similar capacity to self-renew or whether there is different sub-classes of CSCs exist with different self-renewal capacity. While aberrant regulation of self-renewal pathways plays a critical role in CSC biology, targeting these pathways could be an attractive option. However, it will be important to determine the degree to which inhibition of self-renewal can be tolerated by normal cells. It is also unclear whether targeting self-renewal pathways will kill the CSCs or simply suppress their growth. The origin of CSCs is still controversial, thus, future study will be needed to clarify the complex question whether CSCs originate from normal stem cells by acquiring epigenetic and genetic changes required for tumorigenicity or from more differentiated progenitor cells by acquiring self-renewal capacity. Perhaps it is the nature of carcinogenesis itself to utilize a combination of these mechanisms. It is clear that the niche (microenvironment) provides an extrinsic component to normal HSCs that help in their survival and self-renewal. This is also true in solid tumors, wherein stromal fibroblasts play important roles in the initiation and progression of tumors, suggesting that cross talk between cancer cells and their micro environment is a general requirement for neoplasia. CSCs may also exploit the niche or micro-environment in additional ways to maintain their behavior and promote cancer growth. Further study will be required to understand the mechanism of interaction of CSCs with niche in order to aid in the development of novel cancer therapies.

As new literature continues to confirm the role of several stem cell signaling pathways in cancer formation and maintenance, it will be interesting to decipher how abnormalities in these stem cell signaling cascades cause cancer and also whether the same tumor-specific mechanisms of growth and survival are active across multiple cancer types. An additional challenge in targeting CSCs is to understand how the properties of stem cells make them particularly difficult to kill. It has been reported that leukemia cancer stem cells reside in a largely quiescent state with regards to cell cycle activity $(119,120)$, thus drugs that target rapidly dividing cells are unlikely to eradicate them. Targeting these cells will require drugs that kill cells independently of cell cycle or that induce the cell cycle specifically in CSCs. Another common feature of CSCs is resistance towards radio- and chemotherapy. It will be important to understand the mechanism of resistance across various cancer types and develop radio- or chemo-sensitizers that preferentially sensitize CSCs to these compounds compared with normal stem cells.

To effectively target CSCs without affecting normal stem cells, it will be important to know how CSCs are similar to normal stem cells. Thus far, studies have shown that CSCs can be eliminated by targeting their stem cell niche, stimulating their differentiation, manipulating the self-renewal pathways or blocking their cell cycle checkpoints (Fig. 3). However, further studies are required to define the mechanism of therapeutic responses of CSCs in various cancers and how it distinguishes them from normal stem cells. It will also be important to develop a sensitive real time method of CSC detection and quantitation to help in the evaluation of clinical end points and in the measurement of treatment success in patients receiving cancer therapy.

The opportunity for discovering new mechanisms and molecular targets for attacking cancer is extremely exciting. While many challenges lie ahead, the investigation of CSCs offers the possibility of generating novel targets that could overcome issues of drug resistance, improve therapeutic efficacy and make cancer treatment more successful and perhaps even curative.

\section{Acknowledgements}

We thank Drs Tracy Adair-Kirk, Robert Delsite and Feng Zhihui for helpful suggestions and comments during the preparation of this manuscript. We thank Drs Daniel Link and Robert Senior for critical reading of the manuscript. We apologize to the many authors of outstanding papers that were not cited here due to space limitations.

\section{References}

1. Nowell PC: The clonal evolution of tumor cell populations. Science 194: 23-28, 1976

2. Denekamp J: Tumour stem cells: facts, interpretation and consequences. Radiother Oncol 30: 6-10, 1994.

3. Hill RP: Identifying cancer stem cells in solid tumors: case not proven. Cancer Res 66: 1890-1895, 2006.

4. Bonnet D and Dick JE: Human acute myeloid leukemia is organized as a hierarchy that originates from a primitive hematopoietic cell. Nat Med 3: 730-737, 1997.

5. Al-Haij M, Wicha MS, Benito-Hernandez A, Morrison SJ and Clarke MF: Prospective identification of tumorigenic breast cancer cells. Proc Natl Acad of Sci USA 100: 3983-3988, 2003.

6. Singh SK, Clarke ID, Terasaki M, Bonn VE, Hawkins C, Squire J and Dirks PB: Identification of a cancer stem cell in human brain tumors. Cancer Res 63: 5821-5828, 2003.

7. Kim CF, Jackson EL, Woolfenden AE, Lawrence S, Babar I, Vogel S, Crowley D, Bronson RT and Jacks T: Identification of bronchioalveolar stem cells in normal lung and lung cancer. Cell 121: 823-835, 2005.

8. Collins AT, Berry PA, Hyde C, Stower MJ and Maitland NJ: Prospective identification of tumorigenic prostate cancer stem cells. Cancer Res 65: 10946-10951, 2005.

9. Fang D, Nguyen TK, Leishear K, Finko R, Kulp AN, Hotz S, Van Belle PA, Xu X, Elder DE and Herlyn M: A tumorigenic subpopulation with stem cell properties in melanomas. Cancer Res 65: 9328-9337, 2005.

10. Szotek PP, Pieretti-Vanmarcke R, Masiakos PT, Dinulescu DM, Connolly D, Foster R, Dombkowski D, Preffer F, Maclaughlin DT and Donahoe PK: Ovarian cancer side population defines cells with stem cell-like characteristics and Mullerian inhibiting substance responsiveness. Proc Natl Acad Sci USA 103: 11154-11159, 2006.

11. O'Brien CA, Pollett A, Gallinger S and Dick JE: A human colon cancer cell capable of initiating tumour growth in immunodeficient mice. Nature 445: 106-110, 2007.

12. Prince ME, Sivanandan R, Kaczorowski A, Wolf GT, Kaplan MJ, Dalerba P, Weissman IL, Clarke MF and Ailles LE: Identification of a subpopulation of cells with cancer stem cell properties in head and neck squamous cell carcinoma. Proc Natl Acad Sci USA 104: 973-978, 2007.

13. Li C, Heidt DG, Dalerba P, Burant CF, Zhang L, Adsay V, Wicha M, Clarke MF and Simeone DM: Identification of pancreatic cancer stem cells. Cancer Res 67: 1030-1037, 2007. 
14. Yang ZF, Ho DW, Ng MN, Lau CK, Yu WC, Ngai P, Chu PW, Lam CT, Poon RT and Fan ST: Significance of CD90+ cancer stem cells in human liver cancer. Cancer Cell 13: 153-166, 2008.

15. Yang YM and Chang JW: Bladder cancer initiating cells (BCICs) are among EMA-CD $44 \mathrm{v}^{+}$subset: novel methods for isolating undetermined cancer stem (initiating) cells. Cancer Invest 26: 725-733, 2008.

16. Malanchi I, Peinado H, Kassen D, Hussenet T, Metzger D, Chambon P, Huber M, Hohl D, Cano A, Birchmeier W and Huelsken J: Cutaneous cancer stem cell maintenance is dependent on beta-catenin signalling. Nature 452: 650-653, 2008.

17. Kelly PN, Dakic A, Adams JM, Nutt SL and Strasser A: Tumor growth need not be driven by rare cancer stem cells. Science 317: $337,2007$.

18. Shipitsin M and Polyak K: The cancer stem cell hypothesis: in search of definitions, markers, and relevance. Lab Invest 88: 459-463, 2008

19. Shmelkov SV, Butler JM, Hooper AT, Hormigo A, Kushner J, Milde T, St Clair R, Baljevic M, White I, Jin DK, Chadburn A, Murphy AJ, Valenzuela DM, Gale NW, Thurston G, Yancopoulos GD, D'Angelica M, Kemeny N, Lyden D and Rafii S: CD133 expression is not restricted to stem cells, and both $\mathrm{CD} 133^{+}$and $\mathrm{CD} 133^{-}$metastatic colon cancer cells initiate tumors. J Clin Invest 118: 2111-2120, 2008.

20. Campos LS: Neurospheres: insights into neural stem cell biology. J Neurosci Res 78: 761-769, 2004.

21. Campos LS, Decker L, Taylor V and Skarnes W: Notch, epidermal growth factor receptor, and beta1-integrin pathways are coordinated in neural stem cells. J Biol Chem 281: 5300-5309, 2006

22. Screpanti I, Bellavia D, Campese AF and Frati Land Gulino A: Notch, a unifying target in T-cell acute lymphoblastic leukemia? Trends Mol Med 9: 30-35, 2003.

23. Mumm JS, Schroeter EH, Saxena MT, Griesemer A, Tian X, Pan DJ, Ray WJ and Kopan R: A ligand-induced extracellular cleavage regulates gamma-secretase-like proteolytic activation of Notch1. Mol Cell 5: 197-206, 2000.

24. Ellisen LW, Bird J, West DC, Soreng AL, Reynolds TC, Smith SD and Sklar J: TAN-1, the human homolog of the Drosophila notch gene, is broken by chromosomal translocations in T lymphoblastic neoplasms. Cell 66: 649-661, 1991.

25. Kojika $S$ and Griffin JD: Notch receptors and hematopoiesis. Exp Hematol 29: 1041-1052, 2001.

26. Androutsellis-Theotokis A, Leker RR, Soldner F, Hoeppner DJ, Ravin R, Poser SW, Rueger MA, Bae SK, Kittappa R and McKay RD: Notch signalling regulates stem cell numbers in vitro and in vivo. Nature 442: 823-826, 2006.

27. Robey E, Chang D, Itano A, Cado D, Alexander H, Lans D, Weinmaster G and Salmon P: An activated form of Notch influences the choice between CD4 and CD8 T cell lineages. Cell 87: 483-492, 1996

28. Pear WS, Aster JC, Scott ML, Hasserjian RP, Soffer B, Sklar J and Baltimore D: Exclusive development of T cell neoplasms in mice transplanted with bone marrow expressing activated Notch alleles. J Exp Med 183: 2283-2291, 1996.

29. Smith GH, Gallahan D, Diella F, Jhappan C, Merlino G and Callahan R: Constitutive expression of a truncated INT3 gene in mouse mammary epithelium impairs differentiation and functional development. Cell Growth Differ 6: 563-577, 1995.

30. Dontu G, Jackson KW, McNicholas E, Kawamura MJ, Abdallah WM and Wicha MS: Role of Notch signaling in cellfate determination of human mammary stem/progenitor cells. Breast Cancer Res 6: 605-615, 2004

31. Jhappan C, Gallahan D, Stahle C, Chu E, Smith GH, Merlino G and Callahan R: Expression of an activated Notch-related int-3 transgene interferes with cell differentiation and induces neoplastic transformation in mammary and salivary glands. Genes Dev 6 : 345-355, 1992.

32. Gallahan D, Jhappan C, Robinson G, Hennighausen L, Sharp R, Kordon E, Callahan R, Merlino G and Smith GH: Expression of a truncated Int 3 gene in developing secretory mammary epithelium specifically retards lobular differentiation resulting in tumorigenesis. Cancer Res 56: 1775-1785, 1996.

33. Uyttendaele H, Soriano JV, Montesano R and Kitajewski J: Notch4 and Wnt-1 proteins function to regulate branching morphogenesis of mammary epithelial cells in an opposing fashion. Dev Biol 196: 204-217, 1998.

34. Soriano JV, Uyttendaele H, Kitajewski J and Montesano R Expression of an activated Notch4(int-3) oncoprotein disrupts morphogenesis and induces an invasive phenotype in mammary epithelial cells in vitro. Int J Cancer 86: 652-659, 2000.
35. Miller FD and Gauthier AS: Timing is everything: making neurons versus glia in the developing cortex. Neuron 54: 357-369, 2007.

36. Liu CY, Apuzzo ML and Tirrell DA: Engineering of the extracellular matrix: working toward neural stem cell programming and neurorestoration - concept and progress report. Neurosurgery 52: 1154-1165, 2003.

37. Morrison SJ: Neuronal differentiation: proneural genes inhibit gliogenesis. Curr Biol 11: 349-351, 2001.

38. Shih AH and Holland EC: Notch signaling enhances nestin expression in gliomas. Neoplasia 8: 1072-1082, 2006

39. Reguart N, He B, Taron M, You L, Jablons DM and Rosell R: The role of Wnt signaling in cancer and stem cells. Future Oncol 1: 787-797, 2005.

40. Kolligs FT, Hu G, Dang CV and Fearon ER: Neoplastic transformation of RK3E by mutant beta-catenin requires deregulation of Tcf/Lef transcription but not activation of c-myc expression. Mol Cell Biol 19: 5696-5706, 1999.

41. Alonso Land Fuchs E: Stem cells in the skin: waste not, Wnt not. Genes Dev 17: 1189-1200, 2003.

42. Li Y, Welm B, Podsypanina K, Huang S, Chamorro M, Zhang X, Rowlands T, Egeblad M, Cowin P, Werb Z, Tan LK, Rosen JM and Varmus HE: Evidence that transgenes encoding components of the Wnt signaling pathway preferentially induce mammary cancers from progenitor cells. Proc Natl Acad Sci USA 100: $15853-15858,2003$.

43. Reya $\mathrm{T}$ and Clevers $\mathrm{H}$ : Wnt signalling in stem cells and cancer Nature 434: 843-850, 2005.

44. Lowry WE, Blanpain C, Nowak JA, Guasch G, Lewis L and Fuchs E: Defining the impact of beta-catenin/Tcf transactivation on epithelial stem cells. Genes Dev 19: 1596-1611, 2005.

45. Woodward WA, Chen MS, Behbod F and Rosen JM: On mammary stem cells. J Cell Sci 118 (Pt 16): 3585-3594, 2005.

46. Reya T, Duncan AW, Ailles L, Domen J, Scherer DC, Willert K, Hintz L, Nusse R and Weissman IL: A role for Wnt signalling in self-renewal of haematopoietic stem cells. Nature 423: 409-414, 2003.

47. Willert K, Brown JD, Danenberg E, Duncan AW, Weissman IL, Reya T, Yates JR III and Nusse R: Wnt proteins are lipidmodified and can act as stem cell growth factors. Nature 423: 448-452, 2003

48. de Lau W, Barker N and Clevers H: WNT signaling in the normal intestine and colorectal cancer. Front Biosci 12: 471-491, 2007.

49. Chenn A and Walsh CA: Regulation of cerebral cortical size by control of cell cycle exit in neural precursors. Science 297: 365-369, 2002

50. Zechner D, Fujita Y, Hulsken J, Muller T, Walther I, Taketo MM, Crenshaw EB III, Birchmeier W and Birchmeier C: beta-Catenin signals regulate cell growth and the balance between progenitor cell expansion and differentiation in the nervous system. Dev Biol 258: 406-418, 2003.

51. Zurawel RH, Chiappa SA, Allen C and Raffel C: Sporadic medulloblastomas contain oncogenic beta-catenin mutations. Cancer Res 58: 896-899, 1998.

52. Dahmen RP, Koch A, Denkhaus D, Tonn JC, Sorensen N, Berthold F, Behrens J, Birchmeier W, Wiestler OD and Pietsch T: Deletions of AXIN1, a component of the WNT/wingless pathway, in sporadic medulloblastomas. Cancer Res 61: 7039-7043, 2001

53. Baeza N, Masuoka J, Kleihues P and Ohgaki H: AXIN1 mutations but not deletions in cerebellar medulloblastomas. Oncogene 22 632-636, 2003

54. Liu BY, McDermott SP, Khwaja SS and Alexander CM: The transforming activity of Wnt effectors correlates with their ability to induce the accumulation of mammary progenitor cells. Proc Natl Acad Sci USA 101: 4158-4163, 2004.

55. Fleming HE, Janzen V, Lo Celso C, Guo J, Leahy KM, Kronenberg HM and Scadden DT: Wnt signaling in the niche enforces hematopoietic stem cell quiescence and is necessary to preserve self-renewal in vivo. Cell Stem Cell 2: 274-283, 2008.

56. Hahn H, Wicking C, Zaphiropoulous PG, Gailani MR, Shanley S, Chidambaram A, Vorechovsky I, Holmberg E, Unden AB, Gillies S, Negus K, Smyth I, Pressman C, Leffell DJ, Gerrard B, Goldstein AM, Dean M, Toftgard R, Chenevix-Trench G, Wainwright $\mathrm{B}$ and Bale AE: Mutations of the human homolog of Drosophila patched in the nevoid basal cell carcinoma syndrome. Cell 85: 841-851, 1996. 
57. Johnson RL, Rothman AL, Xie J, Goodrich LV, Bare JW Bonifas JM, Quinn AG, Myers RM, Cox DR, Epstein EH Jr and Scott MP: Human homolog of patched, a candidate gene for the basal cell nevus syndrome. Science 272: 1668-1671, 1996.

58. Oro AE, Higgins KM, Hu Z, Bonifas JM, Epstein EH Jr and Scott MP: Basal cell carcinomas in mice overexpressing sonic hedgehog. Science 276: 817-821, 1997.

59. Nilsson M, Unden AB, Krause D, Malmqwist U, Raza K, Zaphiropoulos PG and Toftgard R: Induction of basal cell carcinomas and trichoepitheliomas in mice overexpressing GLI-1. Proc Natl Acad Sci USA 97: 3438-3443, 2000.

60. Grachtchouk M, Mo R, Yu S, Zhang X, Sasaki H, Hui CC and Dlugosz AA: Basal cell carcinomas in mice overexpressing Gli2 in skin. Nat Genet 24: 216-217, 2000.

61. Bale AE and Yu KP: The hedgehog pathway and basal cell carcinomas. Hum Mol Genet 10: 757-762, 2001

62. Goodrich LV, Milenkovic L, Higgins KM and Scott MP: Altered neural cell fates and medulloblastoma in mouse patched mutants. Science 277: 1109-1113, 1997

63. Raffel C, Jenkins RB, Frederick L, Hebrink D, Alderete B, Fults DW and James CD: Sporadic medulloblastomas contain PTCH mutations. Cancer Res 57: 842-845, 1997.

64. Reifenberger J, Wolter M, Weber RG, Megahed M, Ruzicka T, Lichter P and Reifenberger G: Missense mutations in $\mathrm{SMOH}$ in sporadic basal cell carcinomas of the skin and primitive neuroectodermal tumors of the central nervous system. Cancer Res 58: 1798-1803, 1998.

65. Palma V and Ruiz i Altaba A: Hedgehog-GLI signaling regulates the behavior of cells with stem cell properties in the developing neocortex. Development 131: 337-345, 2004.

66. Taylor MD, Liu L, Raffel C, Hui CC, Mainprize TG, Zhang X, Agatep R, Chiappa S, Gao L, Lowrance A, Hao A, Goldstein AM, Stavrou T, Scherer SW, Dura WT, Wainwright B, Squire JA, Rutka JT and Hogg D: Mutations in SUFU predispose to medulloblastoma. Nat Genet 31: 306-310, 2002.

67. Kinzler KW, Bigner SH, Bigner DD, Trent JM, Law ML, O'Brien SJ, Wong AJ and Vogelstein B: Identification of an amplified, highly expressed gene in a human glioma. Science 236: 70-73, 1987.

68. Liu S, Dontu G, Mantle ID, Patel S, Ahn NS, Jackson KW, Suri P and Wicha MS: Hedgehog signaling and $\mathrm{Bmi}-1$ regulate selfrenewal of normal and malignant human mammary stem cells. Cancer Res 66: 6063-6071, 2006.

69. Bhardwaj G, Murdoch B, Wu D, Baker DP, Williams KP, Chadwick K, Ling LE, Karanu FN and Bhatia M: Sonic hedgehog induces the proliferation of primitive human hematopoietic cells via BMP regulation. Nat Immunol 2: 172-180, 2001.

70. Clement V, Sanchez P, de Tribolet N, Radovanovic I and Ruiz i Altaba A: HEDGEHOG-GLI1 signaling regulates human glioma growth, cancer stem cell self-renewal, and tumorigenicity. Curr Biol 17: 165-172, 2007

71. Valk-Lingbeek ME, Bruggeman SW and van Lohuizen M: Stem cells and cancer; the polycomb connection. Cell 118: 409-418, 2004

72. Park IK, Qian D, Kiel M, Becker MW, Pihalja M, Weissman IL, Morrison SJ and Clarke MF: Bmi-1 is required for maintenance of adult self-renewing haematopoietic stem cells. Nature 423 : 302-305, 2003

73. Molofsky AV, Pardal R, Iwashita T, Park IK, Clarke MF and Morrison SJ: Bmi-1 dependence distinguishes neural stem cell self-renewal from progenitor proliferation. Nature 425: 962-967, 2003

74. Lessard J and Sauvageau G: Bmi-1 determines the proliferative capacity of normal and leukaemic stem cells. Nature 423 : 255-260, 2003

75. van der Lugt NM, Domen J, Linders K, van Roon M, Robanus-Maandag E, te Riele H, van der Valk M, Deschamps J, Sofroniew M and van Lohuizen M: Posterior transformation, neurological abnormalities, and severe hematopoietic defects in mice with a targeted deletion of the bmi-1 proto-oncogene. Genes Dev 8: 757-769, 1994

76. Scrideli CA, Simoes AL, Defavery R, Bernardes JE, Duarte MH and Tone LG: Childhood B lineage acute lymphoblastic leukemia clonality study by the polymerase chain reaction. J Pediatr Hematol Oncol 19: 516-522, 1997.

77. George AA, Franklin J, Kerkof K, Shah AJ, Price M, Tsark E, Bockstoce D, Yao D, Hart N, Carcich S, Parkman R, Crooks GM, and Weinberg K: Detection of leukemic cells in the CD34(+) CD38(-) bone marrow progenitor population in children with acute lymphoblastic leukemia. Blood 97: 3925-3930, 2001.
78. Jamieson $\mathrm{CH}$, Weissman IL and Passegue E: Chronic versus acute myelogenous leukemia: a question of self-renewal. Cancer Cell 6: 531-533, 2004.

79. Krivtsov AV, Twomey D, Feng Z, Stubbs MC, Wang Y, Faber J, Levine JE, Wang J, Hahn WC, Gilliland DG, Golubt R and Armstrong SA: Transformation from committed progenitor to leukaemia stem cell initiated by MLL-AF9. Nature 442: 818-822, 2006.

80. Wu XZ: Origin of cancer stem cells: the role of self-renewal and differentiation. Ann Surg Oncol 15: 407-414, 2008

81. Singh SK, Hawkins C, Clarke ID, Squire JA, Bayani J, Hide T, Henkelman RM, Cusimano MD and Dirks PB: Identification of human brain tumour initiating cells. Nature 432: 396-401, 2004.

82. Gottesman MM, Fojo T and Bates SE: Multidrug resistance in cancer: role of ATP-dependent transporters. Nat Rev 2: 48-58, 2002.

83. Wolf NS, Kone A, Priestley GV and Bartelmez SH: In vivo and in vitro characterization of long-term repopulating primitive hematopoietic cells isolated by sequential Hoechst 33342rhodamine 123 FACS selection. Exp Hematol 21: 614-622, 1993.

84. Leemhuis T, Yoder MC, Grigsby S, Aguero B, Eder P and Srour EF: Isolation of primitive human bone marrow hematopoietic progenitor cells using Hoechst 33342 and Rhodamine 123. Exp Hematol 24: 1215-1224, 1996.

85. Bradford GB, Williams B, Rossi R and Bertoncello I: Quiescence, cycling, and turnover in the primitive hematopoietic stem cell compartment. Exp Hematol 25: 445-453, 1997.

86. Bertolini F, Battaglia M, Lanza A, Gibelli N, Palermo B, Pavesi L, Caprotti M and Robustelli della Cuna G: Multilineage long-term engraftment potential of drug-resistant hematopoietic progenitors. Blood 90: 3027-3036, 1997.

87. Tang C, Ang BT and Pervaiz S: Cancer stem cell: target for anti-cancer therapy. FASEB J 21: 3777-3785, 2007.

88. Hirschmann-Jax C, Foster AE, Wulf GG, Nuchtern JG, Jax TW, Gobel U, Goodell MA and Brenner MK: A distinct 'side population' of cells with high drug efflux capacity in human tumor cells. Proc Natl Acad Sci USA 101: 14228-14233, 2004.

89. Doyle JJ, Doyle JL and Brown AH: Origins, colonization, and lineage recombination in a widespread perennial soybean polyploid complex. Proc Natl Acad Sci USA 96: 10741-10745, 1999.

90. Allikmets R, Schriml LM, Hutchinson A, Romano-Spica V and Dean M: A human placenta-specific ATP-binding cassette gene (ABCP) on chromosome $4 \mathrm{q} 22$ that is involved in multidrug resistance. Cancer Res 58: 5337-5339, 1998

91. Goodell MA, Brose K, Paradis G, Conner AS and Mulligan RC: Isolation and functional properties of murine hematopoietic stem cells that are replicating in vivo. J Exp Med 183: 1797-1806, 1996.

92. Zhou S, Schuetz JD, Bunting KD, Colapietro AM, Sampath J, Morris JJ, Lagutina I, Grosveld GC, Osawa M, Nakauchi H and Sorrentino BP: The ABC transporter Bcrp1/ABCG2 is expressed in a wide variety of stem cells and is a molecular determinant of the side-population phenotype. Nat Med 7: 1028-1034, 2001

93. Liu G, Yuan X, Zeng Z, Tunici P, Ng H, Abdulkadir IR, Lu L, Irvin D, Black KL and Yu JS: Analysis of gene expression and chemoresistance of $\mathrm{CD}_{133^{+}}$cancer stem cells in glioblastoma. Mol Cancer 5: 67-79, 2006.

94. Bao S, Wu Q, McLendon RE, Hao Y, Shi Q, Hjelmeland AB, Dewhirst MW, Bigner DD and Rich JN: Glioma stem cells promote radioresistance by preferential activation of the DNA damage response. Nature 444: 756-760, 2006.

95. Phillips TM, McBride WH and Pajonk F: The response of $\mathrm{CD} 24(-/$ low $) / \mathrm{CD} 44^{+}$breast cancer-initiating cells to radiation. J Natl Cancer Inst 98: 1777-1785, 2006.

96. Woodward WA, Chen MS, Behbod F, Alfaro MP, Buchholz TA and Rosen JM: WNT/beta-catenin mediates radiation resistance of mouse mammary progenitor cells. Proc Natl Acad Sci USA 104: 618-623, 2007.

97. Li L and Xie T: Stem cell niche: structure and function. Annu Rev Cell Dev Biol 21: 605-631, 2005.

98. Clarke MF and Fuller M: Stem cells and cancer: two faces of eve. Cell 124: 1111-1115, 2006

99. Jin L, Hope KJ, Zhai Q, Smadja-Joffe F and Dick JE: Targeting of CD44 eradicates human acute myeloid leukemic stem cells. Nat Med 12: 1167-1174, 2006. 
100. Krause DS, Lazarides K, von Andrian UH and Van Etten RA Requirement for CD44 in homing and engraftment of BCRABL-expressing leukemic stem cells. Nat Med 12: 1175-1180, 2006.

101. Calabrese C, Poppleton H, Kocak M, Hogg TL, Fuller C, Hamner B, Oh EY, Gaber MW, Finklestein D, Allen M, Frank A, Bayazitov IT, Zakharenko SS, Gajjar A, Davidoff A and Gilbertson RJ: A perivascular niche for brain tumor stem cells. Cancer Cell 11: 69-82, 2007.

102. Piccirillo SG, Reynolds BA, Zanetti N, Lamorte G, Binda E, Broggi G, Brem H, Olivi A, Dimeco F and Vescovi AL: Bone morphogenetic proteins inhibit the tumorigenic potential of human brain tumour-initiating cells. Nature 444: 761-765, 2006.

103.Fan X, Matsui W, Khaki L, Stearns D, Chun J, Li YM and Eberhart CG: Notch pathway inhibition depletes stem-like cells and blocks engraftment in embryonal brain tumors. Cancer Res 66: 7445-7452, 2006

104.Dang TP, Gazdar AF, Virmani AK, Sepetavec T, Hande KR, Minna JD, Roberts JR and Carbone DP: Chromosome 19 translocation, overexpression of Notch3, and human lung cancer. J Natl Cancer Inst 92: 1355-1357, 2000.

105.Pece S, Serresi M, Santolini E, Capra M, Hulleman E, Galimberti V, Zurrida S, Maisonneuve P, Viale G and Di Fiore PP: Loss of negative regulation by Numb over Notch is relevant to human breast carcinogenesis. J Cell Biol 167: 215-221, 2004.

106. Tonon G, Modi S, Wu L, Kubo A, Coxon AB, Komiya T, O'Neil K, Stover K, El-Naggar A, Griffin JD, Kirsch IR and Kaye FJ: $\mathrm{t}(11 ; 19)(\mathrm{q} 21 ; \mathrm{p} 13)$ translocation in mucoepidermoid carcinoma creates a novel fusion product that disrupts a Notch signaling pathway. Nat Genet 33: 208-213, 2003.

107. Miyamoto Y, Maitra A, Ghosh B, Zechner U, Argani P Iacobuzio-Donahue CA, Sriuranpong V, Iso T, Meszoely IM, Wolfe MS, Hruban RH, Ball DW, Schmid RM and Leach SD: Notch mediates TGF alpha-induced changes in epithelial differentiation during pancreatic tumorigenesis. Cancer Cell 3: 565-576, 2003.

108. He B, You L, Uematsu K, Xu Z, Lee AY, Matsangou M, McCormick F and Jablons DM: A monoclonal antibody against Wnt-1 induces apoptosis in human cancer cells. Neoplasia 6: 7-14, 2004.

109. You L, He B, Xu Z, Uematsu K, Mazieres J, Fujii N, Mikami I, Reguart N, McIntosh JK, Kashani-Sabet M, McCormick F and Jablons DM: An anti-Wnt-2 monoclonal antibody induces apoptosis in malignant melanoma cells and inhibits tumor growth. Cancer Res 64: 5385-5389, 2004.
110. You L, He B, Xu Z, Uematsu K, Mazieres J, Mikami I, Reguart N, Moody TW, Kitajewski J, McCormick F and Jablons DM: Inhibition of Wnt-2-mediated signaling induces programmed cell death in non-small-cell lung cancer cells. Oncogene 23: 6170-6174, 2004.

111. You L, He B, Uematsu K, Xu Z, Mazieres J, Lee A, McCormick F and Jablons DM: Inhibition of Wnt-1 signaling induces apoptosis in beta-catenin-deficient mesothelioma cells. Cancer Res 64: 3474-3478, 2004.

112. Rhee CS, Sen M, Lu D, Wu C, Leoni L, Rubin J, Corr M and Carson DA: Wnt and frizzled receptors as potential targets for immunotherapy in head and neck squamous cell carcinomas. Oncogene 21: 6598-6605, 2002.

113. Mazieres J, You L, He B, Xu Z, Twogood S, Lee AY, Reguart N, Batra S, Mikami I and Jablons DM: Wnt2 as a new therapeutic target in malignant pleural mesothelioma. Int J Cancer 117: 326-332, 2005

114. Williams JA, Guicherit OM, Zaharian BI, Xu Y, Chai L, Wichterle H, Kon C, Gatchalian C, Porter JA, Rubin LL and Wang FY: Identification of a small molecule inhibitor of the hedgehog signaling pathway: effects on basal cell carcinoma-like lesions. Proc Natl Acad Sci USA 100: 4616-4621, 2003.

115. Kiselyov AS: Targeting the hedgehog signaling pathway with small molecules. Anticancer Agents Med Chem 6: 445-449, 2006.

116. Berman DM, Karhadkar SS, Hallahan AR, Pritchard JI, Eberhart CG, Watkins DN, Chen JK, Cooper MK, Taipale J, Olson JM and Beachy PA: Medulloblastoma growth inhibition by hedgehog pathway blockade. Science 297: 1559-1561, 2002.

117. Romer J and Curran T: Targeting medulloblastoma: smallmolecule inhibitors of the Sonic Hedgehog pathway as potential cancer therapeutics. Cancer Res 65: 4975-4978, 2005.

118. Rubin LL and de Sauvage FJ: Targeting the Hedgehog pathway in cancer. Nat Rev Drug Discov 5: 1026-1033, 2006.

119. Guan Y, Gerhard B and Hogge DE: Detection, isolation, and stimulation of quiescent primitive leukemic progenitor cells from patients with acute myeloid leukemia (AML). Blood 101: 3142-3149, 2003.

120. Holyoake T, Jiang X, Eaves C and Eaves A: Isolation of a highly quiescent subpopulation of primitive leukemic cells in chronic myeloid leukemia. Blood 94: 2056-2064, 1999. 